\title{
A.A. Aletdinova
}

\section{INNOVATIVE DEVELOPMENT OF THE AGRO-INDUSTRIAL COMPLEX ON THE BASIS OF DISRUPTIVE TECHNOLOGIES}

\author{
А.А. Алетдинова \\ ИННОВАЦИОННОЕ РАЗВИТИЕ \\ АГРОПРОМЫШЛЕННОГО КОМПЛЕКСА \\ НА ОСНОВЕ ПРОРЫВНЫХ ТЕХНОЛОГИЙ
}

Technological progress has led to the emergence of new disruptive technologies: mobile Internet, artificial intelligence, Internet of things, cloud technology, advanced robotics, autonomous and semi-autonomous vehicles, next-generation genomics, energy storage, 3D printing, advanced materials, renewable energy, exploration, advanced oil and gas exploration and recovery. In the author's opinion, implementing most of them in the agroindustrial complex (AIC) should be considered promising. These technologies will provide a way out of crisis in the cluster, as well as innovative development, radically transforming the agricultural sector. They are expected to contribute to the increment of scientific, labor, environmental, information, communication, and social potentials. They are expected to improve technical equipment, develop industrial and social infrastructures. They are also supposed to contribute to the saving of natural resources. The article describes the main emerging potentials for innovative development of the agro-industrial complex on the basis of disruptive technologies. The massive use of these technologies should allow to reduce the cost of their implementation. The author sees the future of this cluster as an innovative and high-tech one, capable of ensuring food and national security. The agricultural production should be boosted through creating a unified information and communication system for remote economic management and social welfare, logistics, consulting services, education, and public services; robotics and automation of technological processes; genetic industry; the use of new technologies, materials, renewable energy, all of which would ultimately lead to a more harmonious interaction of man and biosphere. In the future the agro-industrial cluster is seen as innovative and high-tech, capable of ensuring food and national security.

INNOVATIVE DEVELOPMENT; DISRUPTIVE TECHNOLOGIES; AGRICULTURE; INTENSIFICATION OF PRODUCTION; POTENTIAL EFFECT OF INTRODUCTION.

Научно-технический прогресс привел к появлению новых прорывных технологий: мобильного интернета, искусственного интеллекта, интернета вещей, облачных технологий, прогрессивных роботов, автономных и полуавтономных транспортных средств, генной индустрии, аккумулирования и накопления энергии, 3-D печати, материалов нового поколения, возобновляемой энергии, разведки, добычи и восполнения нефти и газа. Следует считать перспективным использование большинства из них в агропромышленном комплексе. Они обеспечат не только выход из кризиса этого кластера, но и инновационное развитие, кардинально преобразив аграрную сферу. Ожидается приращение научного, экологического, информационно-коммуникационного потенциалов, повышение технической оснащенности, развитие производственной и социальной инфраструктуры, сохранение природного потенциала. Первоначальное снижение трудового и социального потенциалов за счет отмирания ряда профессий, сокращения низкоквалифицированных работников и обострения их социальной незащищенности должно компенсироваться улучшением качества жизни и труда, востребованностью специалистов новых для агропромышленного комплекса специальностей, повышением производительности труда. В будущем эти потенциалы тоже будут расти. Рассмотрены основные появляющиеся резервы инновационного развития агропромышленного комплекса на основе прорывных технологий. Массовое использование этих технологий должно позволить снизить стоимость их внедрения. Переход к интенсификации аграрного производства на основе создания единой информационно-коммуникационной системы дистанционного управления хозяйственной деятельностью и социального обеспечения, логистики, консультационных служб, образования, государственных услуг, роботизации и автоматизации технологических процессов, генной индустрии, использования новых технологий, материалов, возобновляемой энергии реализует гармоничное взаимодействие человека и биосферы. В перспективе агропромышленный кластер видится инновационным и высокотехнологичным, способным обеспечить продовольственную и национальную безопасность.

ИННОВАЦИОННОЕ РАЗВИТИЕ; ПРОРЫВНЫЕ ТЕХНОЛОГИИ; АГРОПРОМЫШЛЕННЫЙ КОМПЛЕКС; ИНТЕНСИФИКАЦИЯ ПРОИЗВОДСТВА; ПОТЕНЦИАЛ; ЭФФЕКТ ОТ ВНЕДРЕНИЯ. 
Introduction. The agro-industrial complex is a cluster which is characterized by the presence of groups of geographically accumulated enterprises with a common specialization, a network of research and educational organizations and a common social environment. In our view, the agro-industrial cluster is a stable network of interacting economic agents which is able to meet the needs of the growing population for high-quality food products based on introducing innovations.

Let us look at the self-definitions of two centers of cluster development in the Novgorod and Kemerovo regions. The agro-industrial cluster in the Novgorod region is a broad partnership, a mobile structure of the most active organizations of the economy in the Novgorod region, created to enhance their competitiveness and economic potential through effective cooperation in the production, processing, transportation, promotion, sales and the provision of consulting and educational services, by means of organizing a regulated flow of information processes between them [1]. The agro-industrial cluster in the Kemerovo region is a voluntary and informal association of organizations from different sectors, geographically concentrated in one region, which was created with the aim of production, processing and sales of agricultural products and protection of the environment [2]. They are quite different and they have different functions.

Driven by economical and structural, social, environmental, natural-resource, political institutional, technological and other needs and in accordance with the «Forecast of scientific and technological development of the Russian agro-industrial complex until 2030» [3], the agro-industrial complex is being transformed into an innovation-oriented cluster. If we are talking about the development of the agricultural cluster, it is necessary to describe the qualitative changes in its structure and components. Economic growth is characterized by quantitative changes of the main indicators of the agricultural sector, whereas its development is marked by qualitative changes, based on innovative activities.

Science and technological progress, human activities, political confrontations change the vision of the future. There are changes in the population structure, middle class is shrinking, online public services are starting to develop.
Society, commerce, and social interaction are being transferred to a virtual integrated space; nano-materials are being developed, 3D printing, robotization and intellectualization of technological processes are being introduced; the service industry is expanding, knowledge is becoming the most important resource of the economy. There are uprising global talents, as well as the growing threat of climate changes, hunger, threats to national security, environmental pollution, energy crisis, increasing side effects of technological development; the process of globalization is continuing. The identified trends require the society to take measures to strike a balance between human activities and the environment; to prevent economic, political, technological, social crises; to meet the needs of society. This is only possible through technological (process, product), marketing, organizational, ecological and social innovations [1].

The exhaustibility of resources required that Russia should make a transition from a resourcebased economy to an innovative one. The issues of this transition in the agricultural sector were studied by A.V. Babkin, M.S. Bunin, A.S. Donchenko, B.D. Dokin, O.V. Yolkin, A.L. Nefyodov, O.S. Nogovicina, P.M. Petruskkevitch, I.P. Petruskkevitch, G.S. Prokopyev, T.M. Ryabukhina, A.L. Eidis and other researchers $[5,6,7,8,9,10]$.

The complex structure of the agricultural cluster requires using all types of innovation for its modernization. The innovations provide the intensification of production at a new level, the reconstruction of the social infrastructure, sustainable development.

The purpose of this study is in determining the main effects of introducing disruptive technologies in agriculture.

Modern state of the agro-industrial complex. The agro-industrial complex (AIC) is the backbone cluster of the Russian economy which forms the agricultural market, economic, social and employment potentials of rural areas, ensuring food and economic security.

Currently, it requires serious reformation and modernization. Power supply of agricultural organizations in Russia has been gradually decreasing. In comparison with 2000, it decreased by more than 1.5 times, which does not make it possible to go to intensive 
production [11]. The average service life of machinery, vehicles and equipment in agriculture is significantly below the same indicators in the manufacturing industry, electric power industry, gas and water industries, as well as in the whole economy [11]. In addition, the renovation rate of vehicle and tractor stock does not allow modernizing it. For example, as of January 1, 2014, the share of the agricultural equipment older than ten years in the Novosibirsk region accounted for $83.2 \%$ of the tractors, $68.0 \%$ of the combine harvesters , $43.0 \%$ of the forage harvesters and $93.8 \%$ of the tractor trailers [12]. The nationwide situation is no better. Unfortunately, the indicators of technical and technological renovation of agricultural machinery stock totaled $57-64 \%$ of the values from the State Program plan of 20082012 [13].

A power supply for 100 acres of sown area has an average value of 167.01 horsepower, whereas the required value is $300-350$ horsepower. The availability of agricultural tractors and harvesting machines is achieved only by $45-60 \%$. Studies have shown that the optimal vehicle and tractor stock should comprise 850-900 thousand tractors for developing 30 million hectares of abandoned land or 630 thousand tractors for cultivating the existing one with an average power of $200 \mathrm{hp}$, 200-250 thousand combine harvesters and 60 thousand forage harvesters [14]. According to Nemtsov, the technical potential of the agroindustrial complex is still on the decrease [15]. The national average degree of wear of fixed assets at the end of the year amounts to $47.7 \%$, while in agriculture this figure is slightly lower $(42.5 \%)$, but still not low enough. Zhablin, analyzing the state of agriculture, draws attention to the decrease of human resources and productive capacities by half and the reduction of the remaining capacities by $3-4$ times, so that infrastructure indicators are fixed at the level of the 1990s [16].

In recent times the number of scientific research institutes personnel has been reduced, design offices and laboratories, experimental farms have been disbanded and redesigned. The average age of researchers gives rise to concern [17]. It should be also kept in mind that human capital tends to decline, because of the limited lifespan that may affect the scientific potential of the country.

In this situation, the agro-industrial complex (AIC) requires state support for reconstruction of institutions, infrastructural, technical, human and other resources. At the present time, the 'Strategy for socio-economic development of the agroindustrial complex of the Russian Federation for the period until the 2020' and 'Strategy for sustainable development of rural territories of the Russian Federation for the period up to 2030' have been developed in order to modernize the agricultural sector $[18,19]$. Their main innovative aspects are reflected in the following tasks:

- creating the conditions for soil fertility preservation and restoration, development of agricultural land melioration;

- increasing the effectiveness of internal and external agricultural, commodity and food markets regulation;

- technical and technological modernization, encouragement of investments and innovative development of the agro-industrial complex;

- creation of organizational and economic conditions for expanded reproduction;

- improvement of an information system in the agro-industrial complex;

- scientific support for the implementation of measures for the development of agricultural production and agricultural, commodity and food markets regulation;

- improving governance in the field of agriculture;

- increasing employment, level and quality of life of the rural population.

State support of the agro-industrial complex is carried out within the framework of the 'State Program for Development of Agriculture and Regulation of Agricultural Commodities Markets in 2013-2020' in the form of subsidies from the Federal budget to the budgets of the subjects of the Russian Federation [20]. Their basic forms, aimed at innovative development, are shown in Tab. 1.

The greatest support is provided for integrated development of social and engineering infrastructure objects, the construction and reconstruction of roads in the rural area. Within this Program there are no subsidies to agricultural machinery producers and for the implementation of innovative projects, which generally hampers innovative development. 
State support of innovative development of agro-industrial complex as of 30.12.2015 |(compiled based on the data from [21])

\begin{tabular}{|l|c|}
\hline \multicolumn{1}{|c|}{ Directions of state support } & $\begin{array}{c}\text { Provided in the current } \\
\text { year, thousand rubles }\end{array}$ \\
\hline $\begin{array}{l}\text { Subsidies for partial compensation of the direct costs incurred for creating and } \\
\text { upgrading the agro-industrial complex }\end{array}$ & 1564633 \\
\hline Subsidies to producers of agricultural machinery & - \\
\hline Subsidies for implementing promising innovative projects of the agro-industrial complex & - \\
\hline $\begin{array}{l}\text { Subsidies for integrated development of social and engineering infrastructure objects in } \\
\text { the settlements located in the rural area, the construction and reconstruction of roads }\end{array}$ & 9361719 \\
\hline Subsidies to support local initiatives of citizens living in rural areas & 194459 \\
\hline $\begin{array}{l}\text { Subsidies for construction, reconstruction, technical re-equipment of irrigation and } \\
\text { drainage systems for general and individual use and separately located waterworks } \\
\text { belonging to agricultural producers }\end{array}$ & 1950700 \\
\hline
\end{tabular}

The producers are wary of new technologies and innovations. According to the statistical study of the agricultural organizations of the Novosibirsk region (with a sample size of 53 farms) the main factors hindering innovation are the lack of own funds, high cost of innovation and the degree of risk [9].

Thus, the agro-industrial complex requires serious reformation and modernization. This is impossible without technical re-equipment. The only possible way to pull the cluster out of the crisis is through innovation with the support from agricultural producers and the state.

Prospects for application of disruptive technologies in the agro-industrial complex. Disruptive technologies are achievements 'which transform life, business and the global economy'. They contribute to wide-scale economic reforms and breakthroughs over the next years [22]. Currently, there are twelve most important technologies:

1) mobile Internet;

2) artificial intelligence;

3) Internet of things;

4) cloud;

5) advanced robotics;

6) autonomous and semi-autonomous vehicles;

7) next-generation genomics;

8) energy storage;

9) 3D printing;

10) advanced materials;
11) advanced oil and gas exploration and recovery; [17].

12) renewable energy, i.e.,solar and wind

McKinsey \& Company estimated that the global economic effect from implementing these technologies is expected to be between $\$ 14$ trillion and $\$ 33$ trillion a year in 2025 (Tab. 2).

Table 2

Potential economic impact in $\mathbf{2 0 2 5}$

from the implementation of disruptive technologies (based on the data of [22]), trillion \$

\begin{tabular}{|l|c|}
\hline \multicolumn{1}{|c|}{ Disruptive technologies } & Economic effect \\
\hline Mobile Internet & $3.7-10.8$ \\
\hline Artificial intelligence & $5.2-6.7$ \\
\hline Internet of things & $2.7-6.2$ \\
\hline Cloud & $1.7-6.2$ \\
\hline Advanced robotics & $1.7-4.5$ \\
\hline $\begin{array}{l}\text { Autonomous and semi-autonomous } \\
\text { vehicles }\end{array}$ & $0.2-1.9$ \\
\hline Next-generation genomics & $0.7-1.6$ \\
\hline Energy storage & $0.1-0.6$ \\
\hline 3D printing & $0.2-0.6$ \\
\hline Advanced materials & $0.2-0.5$ \\
\hline $\begin{array}{l}\text { Advanced oil and gas exploration } \\
\text { and recovery }\end{array}$ & $0.1-0.5$ \\
\hline Renewable electricity (wind and solar) & $0.2-0.3$ \\
\hline
\end{tabular}


In Russia, the share of expenditures on disruptive technologies amounts to $2.5 \%-7 \%$ of the total expenditures on science [23]. This is one of the reasons why the targets of the Innovative Development Strategy for the period until 2020 have not been achieved yet.

It should be noted that eleven out of twelve of the abovementioned technologies can be applied to the agricultural sector. On the one hand, the agro-industrial complex should be seen as a strategically important cluster in terms of national and food security, while on the other hand, in perspective it can be a highly technological and innovative one. In foreign publications there is a term 'smart agriculture', that means that agriculture is seen as a highly technological cluster, introducing innovations which include the smart generation of agricultural machinery [24].

According to the 'Strategy of socio-economic development of the agro-industrial complex of the Russian Federation for the period until $2020^{\prime}$, it is intended to create a system of efficient, competitive producers on the basis of market mechanisms for improving state agricultural policyusing the mechanism of creating the national innovation system [18].

The agro-industrial cluster can turn into a high-tech one through implementing disruptive technologies. Mobile Internet will provide wireless Internet access based on the WAP Protocol, and, therefore, remote control, network interaction based on the models: $\mathrm{C} 2 \mathrm{M}$, $\mathrm{M} 2 \mathrm{~S}, \mathrm{M} 2 \mathrm{M}, \mathrm{C} 2 \mathrm{~B}, \mathrm{~B} 2 \mathrm{C}, \mathrm{C} 2 \mathrm{C}, \mathrm{B} 2 \mathrm{~B}, \mathrm{C} 2 \mathrm{~A}, \mathrm{~A} 2 \mathrm{C}$, A2A, C2G, G2C, G2G, A2B, B2A, A2G, G2A $\mathrm{B} 2 \mathrm{G}, \mathrm{G} 2 \mathrm{~B}, \mathrm{M} 2 \mathrm{~B}, \mathrm{~B} 2 \mathrm{M}, \mathrm{M} 2 \mathrm{~A}, \mathrm{~A} 2 \mathrm{M}, \mathrm{M} 2 \mathrm{G}$, and G2M (interaction between consumers, business, government and municipal authorities, intellectual, automated systems, and within these groups). Artificial intelligence will increase software and technical support for information and communication technology equipment (ICT) in organizations and households and for a new generation of robots. For control and automation of the production processes, artificial intelligence, Internet of things, cloud technology should be applied. Robotic tools, robotic systems and devices will ultimately displace human labor in agricultural machinery industry, enterprises and organizations servicing, agriculture, food processing industries, forestry, water sector and fisheries [25]. There will be autonomous technical vehicles with automated control systems and computer vision. Genetic industry will ensure the creation of ethanol, biodiesel from conventional organisms (for example Escherichia coli), manipulation of genes to increase productivity of crops, livestock, forestry and fisheries.

New technologies of energy generation and storage will improve the performance of power lines, which is important for the entire infrastructure of AIC, for electrical devices to function, especially in greenhouses; it is necessary to use renewable sources of energy (for example wind, solar). Circumferential devices for creating physical objects by printing successive layers of materials using 3D digital models, new composite materials may find application in the agricultural machinery industry.

In the Orel region, the GLONASS cluster was created with the aim of development and introduction of new advanced technologies. In 2015, Russian Space Systems presented information and communication technologies for precision farming. They help to reduce costs by $30 \%$ due to the automation of business processes, control over the use of agricultural land and the targeted use of transport. The connection of a vehicle to the GLONASS system allows to control its movements, automatically model economically profitable routes, provide fully automated operation, get quick information about fulfilled tasks, synchronize it with information systems and get its analyses for any period of operation [26]. The first domestically built agricultural unmanned vehicle that performs plant monitoring and spraying was created in the same year [26].

Robotic technology has been developed for several years. The Russian Cognitive Technologies company was the first to develop a prototype of an unmanned tractor. It is equipped with a computer vision system that can detect objects as small as $10-15 \mathrm{~cm}$ at a distance of up to 15-20 m [27]. The All-Russian Research Institute for Mechanization in Agriculture (VIM) has become the leading scientific center developing agricultural robots in Russia. Its researchers regularly participate in agricultural exhibitions showing their inventions. Yet, as noted by Ananiev, the use of agricultural robots is considered to be cost effective only if it replaces at least two employees with its full depreciation period equal to three years [28]. 
Main effects of introducing disruptive technologies in AIC

\begin{tabular}{|c|c|c|}
\hline № & $\begin{array}{c}\text { Potentials for innovative } \\
\text { development }\end{array}$ & Effect from introducing new technologies \\
\hline 1 & Scientific potential & $\begin{array}{l}\text { Demand for scientists and specialists of new professions emerging at the intersection } \\
\text { of different scientific fields } \\
\text { Diffusion of knowledge } \\
\text { Development and creation of new research and experimental design centers and } \\
\text { laboratories }\end{array}$ \\
\hline 2 & Labor potential & $\begin{array}{l}\text { Decrease in the number of employees } \\
\text { Disappearance of a number of professions such as mechanic, milker, etc. } \\
\text { Precarization of low qualified personnel labor } \\
\text { Growing requirements for employees competences } \\
\text { Use of various forms of smart education } \\
\text { Employees having a good command of ICT skills } \\
\text { Better working conditions } \\
\text { Growth of labor productivity }\end{array}$ \\
\hline 2 & Technical equipment & $\begin{array}{l}\text { Automation and intellectualization of technological processes } \\
\text { Good technical equipment not only for individual operations but also for all } \\
\text { technological cycles }\end{array}$ \\
\hline 3 & $\begin{array}{l}\text { Environmental and } \\
\text { ecological potentials }\end{array}$ & $\begin{array}{l}\text { Resource conservation } \\
\text { Less impact (mechanical, chemical, etc.) on the environment } \\
\text { Less space needed for economic activities } \\
\text { Conservation of animals and plants population }\end{array}$ \\
\hline 4 & $\begin{array}{l}\text { Infrastructure } \\
\text { development }\end{array}$ & $\begin{array}{l}\text { Emergence of smart infrastructures of production and the social sphere, smart } \\
\text { settlements }\end{array}$ \\
\hline 5 & $\begin{array}{l}\text { Information and } \\
\text { communications potential }\end{array}$ & $\begin{array}{l}\text { Creating a unified network of information support of management } \\
\text { Development of various forms of network interaction } \\
\text { Increase of information literacy of the population } \\
\text { Growth of information security threats }\end{array}$ \\
\hline 6 & Social potential & $\begin{array}{l}\text { Meting the needs of the population } \\
\text { Hunger problem solution } \\
\text { Improvement of the quality of life }\end{array}$ \\
\hline
\end{tabular}

The economic effect of systematic introduction of disruptive technologies to the agro-industrial complex is expected to be positive in the form of increased yields, productivity and profit. Other effects can also be expected (Tab. 3).

As we see it, disruptive technologies as innovations not only change the production process itself, but also improve scientific, environmental, natural, information and communication potentials, develop technical equipment and upgrade infrastructure. An ambiguous situation prevails in the structure of labor and social potentials. On the one hand, skilled labor is highly required, however, a number of professions will become unnecessary which will lead to a reduction of employees in the AIC and to a further decline of their numbers, and hence of social vulnerability of certain segments of the population, mostly rural. It is necessary to say that the transformation of the agricultural cluster in the high-tech sector, the appearance of smart settlements will attract new high qualified professionals with a wide range of skills to villages. Thus, after the introduction of disruptive technologies to agriculture and the appearance of new professions, labor and social potentials will begin to recover and grow.

Conclusion. The situation in the agroindustrial complex requires adopting measures allowing for economic recovery of the cluster. 
With the threat of economic, political, technological crises it is not enough just to ensure economic growth in the agricultural sector. Production intensification requires innovative development. In our opinion, the future lies in promising disruptive technologies, providing new development opportunities that transform the AIC into a high-tech sector of the economy.

\section{The results of the study.}

1. People change the vision of the future. There are growing threats of climate change, hunger, threats to national security, danger of environmental pollution, energy collapse, as well as unwanted side effects of technology development. The process of globalization is never-ending. The only way to solve these problems is through innovations. In our opinion, they should be associated with the introduction of disruptive technologies: mobile Internet, artificial intelligence, Internet of things, cloud technology, advanced robotics, autonomous and semi-autonomous vehicles, advanced genomics, energy storage, 3D printing, advanced materials, renewable energy, advanced oil and gas exploration and recovery.

2. These technologies (except for the last) can be used for developing the agro-industrial complex. There are already examples of their development and application. The analysis of statistical data shows that agriculture is in a deep crisis. The targets planned in 'The Program of technical and technological updating of agricultural machinery stock' have not been achieved. Technological, social and industrial infrastructures are in need of modernization. Disruptive technologies can not only provide that, but also form a high-tech and innovative cluster.

3. In our view, the implementation of these technologies will provide the following effects. For scientific potential: there will be an increasing demand for scientists and specialists of new professions emerging at the intersection of different fields of science; the diffusion of knowledge; the development and creation of new research and design centers and laboratories. For the labor potential: the number of workers involved in the agro-industrial complex will be reduced; some occupations (such as mechanic, milker, etc.) will stop to exist, while new ones will appear; the employment of low-skilled personnel will become precarious; the requirements for the personnel skills will be increased; various forms of smart education will be used; employees will have a good command of ICT skills; working conditions will be improved; productivity will grow. For technical equipment: technological processes will be automated and intellectualized; there will be full mechanization of not only individual operations, but also all technological cycles. For environmental and natural potentials: there will be resource conservation; reduced impacts on the environment (mechanical, chemical, etc.); less space will be needed for economic activities; the population of plants and animals will be preserved. For infrastructure development: there will be smart infrastructures for production and the social sphere as well as smart settlements. For the information and communication potential: a unified network of information support for management will be created; various forms of network interaction will be developed; there will be an increase in information literacy as well as increased cases of threats to information security. For social potential: the needs of the population will be met; the problem of hunger will be solved; the quality of life will be improved.

4. The introduction of disruptive technologies in the agricultural sector cannot be done only by efforts of agricultural producers. There is a need of highlevel information and communication support for organizations and households to create a single well-developed information and communication system of the agro-industrial complex, including subsystems for remote control of all structural subdivisions of the AIC, logistics, smart settlements, consulting and public services. This requires a development of a state program and a large amount of investment. It is necessary to assume that mass use of advanced technologies allows to reduce the cost of their implementation in organizations and households.

The direction for further research is seen in the assessment of the contribution that disruptive technologies make to scientific, labor, environmental, natural, information and communication potentials; to the new production, technical, and social infrastructure which form the innovative development of the agro-industrial complex. 


\section{REFERENCES}

1. Agropromyshlennyi klaster Kemerovskoi oblasti. URL: http://agrobuy.ru/agrocluster42 (data obrashcheniia: 19.07.2016). (rus)

2. Agropromyshlennyi klaster Novgorodskoi oblasti. URL: http://ckr53.ru/clusters/924/ (data obrashcheniia: 25.08.2016). (rus)

3. Prognoz nauchno-tekhnologicheskogo razvitiia agropromyshlennogo kompleksa Rossii na period do 2030 goda: global'nye vyzovy. Agrarnyi pul's velikoi strany: informatsionnyi biulleten'. 2016. № 4. S. 14-21. (rus)

4. Aletdinova A.A. Statisticheskoe issledovanie innovatsionnoi deiatel'nosti organizatsii: monogr. Novosibirsk: Izd-vo NGTU, 2011. 272 s. (rus)

5. Babkin A.V., Nogovitsyna O.S. Teoretikomethodological aspects of the estimation of efficiency of the innovative infrastructure of the industrial complex of region. St. Petersburg State Polytechnical University Journal. Economics, 2012, no. 1(139), pp. 56-61. (rus)

6. Bunin M.S., Nefedov B.A., Eidis A.L. Upravlenie innovatsionnymi protsessami $\mathrm{v}$ agropromyshlennom komplekse. M.: Rosinformagrotekh, 2006. 295 s. (rus)

7. Donchenko A.S., Pershukevich P.M. Osnovnye napravleniia innovatsionnogo razvitiia sel'skogo khoziaistva Sibiri. Dostizheniia nauki i tekhniki APK. 2016. T. 30. № 2. S. 5-10. (rus)

8. Dokin B.D., Elkin O.V. Tekhnologicheskaia i tekhnicheskaia modernizatsiia rastenievodstva Sibiri. Ekonomika sel'skokhoziaistvennykh i pererabatyvaiushchikh predpriiatii. 2015. № 1. S. 18-22. (rus)

9. Pershukevich I.P., Riabukhina T.M. Mekhanizm innovatsionnogo razvitiia agropromyshlennykh formirovanii Sibiri. Fundamental'nye issledovaniia. 2015. № 12-5. S. 1036-1040. (rus)

10. Prokop'ev G.S. Metodologiia proektirovaniia innovatsionnykh formirovanii $\mathrm{v}$ sel'skom khoziaistve. RISK: Resursy, Informatsiia, Konkurentsiia. 2010. № 4. S. 184-192. (rus)

11. Sait Federal'noi sluzhby gosudarstvennoi statistiki. URL: http://www.gks.ru/ (data obrashcheniia: 19.05.2016). (rus)

12. Nemtsov A.E., Korotkikh V.V. Tekhnika trebuet obnovleniia. Innovatsii - prioritetnyi put' razvitiia agropromyshlennogo kompleksa: sb. mater. VIII Mezhdunar. nauch.-prakt. konf. Kemerovo: Kemerov. GSKhI, 2009. 284 s. (rus)

13. Kuz'min V.N. Razrabotka programm tekhnicheskogo osnashcheniia sel'skogo khoziaistva $v$ rynochnoi ekonomike. M.: FGBNU «Rosinformagrotekh». 2014. 304 s. (rus)

14. Fedorenko V.F. Povyshenie resursoenergoeffektivnosti agropromyshlennogo kompleksa. M.: FGBNU «Rosinformagrotekh». 2014. 284 s. (rus)
15. Nemtsov A.E. Tekhnika - osnova razvitiia agropromyshlennogo kompleksa. Innovatsii $i$ prodovol'stvennaia bezopasnost'. 2015. № 2(8). S. 60-64. (rus)

16. Zhalnin E.V. Agropromyshlennyi kompleks Rossii - stagnatsiia ili razvitie? Traktory $i$ sel'khozmashiny. 2012. № 7. S. 3. (rus)

17. Aleksandrova A.V., Androsenko N.V., Basareva V.G., Bakhmutskaia A.V., Borisov A.A., Vertakova Iu.V., Volkova A.A., Glukhov V.V. i dr. Ekonomika i promyshlennaia politika: teoriia i instrumentarii : koll. monogr. Pod red. d-ra ekon. nauk, prof. A.V. Babkina. SPb.: Izd-vo SPbGPU, 2014. 612 s. (rus)

18. Strategiia sotsial'no-ekonomicheskogo razvitiia agropromyshlennogo kompleksa Rossiiskoi Federatsii na period do 2020 goda (nauchnye osnovy). M. RASKhN. 2011. 101 s. URL: http://www.vniiesh.ru/ documents/document_9509_\%D0\%A1\%D1\%82\%D1 $\% 80 \% \mathrm{D} 0 \% \mathrm{~B} 0 \% \mathrm{D} 1 \% 82 \% \mathrm{D} 0 \% \mathrm{~B} 5 \% \mathrm{D} 0 \% \mathrm{~B} 3 \% \mathrm{D} 0 \% \mathrm{~B} 8$ \%D1\%8F\%20\%D0\%90\%D0\%9F\%D0\%9A\%202020.p df (data obrashcheniia: 08.07.2016). (rus)

19. O ustoichivogo strategii razvitiia sel'skikh territorii RF na period do 2030 g.: Rasporiazh. Pravitel'stva RF № 151-r ot 02.02.2015 g. URL: http://government.ru/media/files/Fw1kbNXVJxQ.pdf (data obrashcheniia: 30.07.2016). (rus)

20. Informatsionnyi spravochnik o merakh i napravleniiakh gosudarstvennoi podderzhki agropromyshlennogo kompleksa RF. URL: http:// www.gp.specagro.ru/ (data obrashcheniia: 03.08.2016). (rus)

21. Informatsionnyi spravochnik o merakh i napravleniiakh gosudarstvennoi podderzhki agropromyshlennogo kompleksa RF. URL: http://www.gp.specagro.ru/reg ion/rf/30/12/2015 (data obrashcheniia: 03.08.2016). (rus)

22. Manyika J. Chui M., Bughin J., Dobbs R., Bisson P., Marrs A. Disruptive technologies: advances that will transform life, business, and the global economy. McKinsey Global Institute, 2013. URL: http://www.mckinsey.com/business-

functions/business-technology/our-insights/disruptivetechnologies (accused July 12, 2016).

23. Rossiiskii innovatsionnyi indeks, Pod red. L.M. Gokhberga. M.: Vysshaia shkola ekonomiki, 2011. 84 s. (rus)

24. Enabling Smart Farming in Europe. URL: http://www.cema-agri.org/page/enabling-smartfarming-europe (accused June 13, 2016).

25. Aletdinova A.A. Diffuziia smart-tekhnologii kak paradigma perekhoda $\mathrm{k}$ sed'momu tekhnologicheskomu ukladu. Teoriia ustoichivogo razvitiia ekonomiki $i$ promyshlennosti. Pod red. A.V. Babkina. SPb.: Izd-vo Sankt-Peterburgskogo politekhn. un-ta Petra Velikogo, 2016. S. 55-77. (rus)

26. Orlovskaia oblast' i Belarus' obsuzhdaiut 
razvitie proektov GLONASS dlia sel'skogo khoziaistva. Novosti internet veshchei. URL: https://iot.ru/selskoekhozyaystvo/2808orlovskaya_oblasts_i_belaruss_obsuz hdaut_razvitie_proektov_glonass_dlya_selsskogo_hozy ajstva (data obrashcheniia: 20.09.2016). (rus)

27. Pervyi prototip samoupravliaemogo traktora predstavlen v Kazani. Novosti internet veshchei. URL: https://iot.ru/selskoe-khozyaystvo/prototip-pervogo-sam oupravlyaemogo-traktora-predstavlen-v-kazani (data obrashcheniia: 20.09.2016). (rus)

28. Anan'ev A.N. Problemy primeneniia robotov v sel'skokhoziaistvennom proizvodstve. URL: http:// www.biz-for.ru/robotics/robotsprobl/robotsprobl.php (data obrashcheniia: 18.08.2016). (rus)

\section{СПИСОК ЛИТЕРАТУРЫ}

1. Агропромышленный кластер Кемеровской области. URL: http://agrobuy.ru/agrocluster42 (дата обращения: 19.07.2016).

2. Агропромышленный кластер Новгородской области. URL: http://ckr53.ru/clusters/924/ (дата обращения: 25.08.2016).

3. Прогноз научно-технологического развития агропромышленного комплекса России на период до 2030 года: глобальные вызовы // Аграрный пульс великой страны: информационный бюллетень. 2016. № 4. С. 14-21.

4. Алетдинова А.А. Статистическое исследование инновационной деятельности организации: моногр. Новосибирск: Изд-во НГТУ, 2011. 272 с.

5. Бабкин А.В., Ноговицына О.С. Научнометодологические аспекты оценки эффективности инновационной инфраструктуры промышленного комплекса региона // Научно-технические ведомости Санкт-Петербургского государственного политехнического университета. Экономические науки. 2012. № 1(139). С. 56-61.

6. Бунин М.С., Нефедов Б.А., Эйдис А.Л. Управление инновационными процессами в агропромышленном комплексе. М.: Росинформагротех, 2006. 295 c.

7. Донченко А.С., Першукевич П.М. Основные направления инновационного развития сельского хозяйства Сибири // Достижения науки и техники АПК. 2016. Т. 30. № 2. С. 5-10.

8. Докин Б.Д., Ёлкин О.В. Технологическая и техническая модернизация растениеводства Сибири // Экономика сельскохозяйственных и перерабатывающих предприятий. 2015. № 1. С. 18-22.

9. Першукевич И.П., Рябухина Т.М. Механизм инновационного развития агропромышленных формирований Сибири // Фундаментальные исследования. 2015. № 12-5. С. 1036-1040.

10. Прокопьев Г.С. Методология проектирования инновационных формирований в сельском хозяйстве // РИСК: Ресурсы, Информация, Конкуренция. 2010. № 4. С. 184-192.

11. Сайт Федеральной службы государственной статистики. URL: http://www.gks.ru/ (дата обрашения: 19.05.2016).

12. Немцов А.Е., Коротких В.В. Техника требует обновления // Инновации - приоритетный путь развития агропромышленного комплекса: сб. матер. VIII Междунар. науч.-практ. конф. Кемерово: Кемеров. ГСХИ, 2009. 284 с

13. Кузьмин В.Н. Разработка программ технического оснащения сельского хозяйства в рыночной экономике. М.: ФГБНУ «Росинформагротех». 2014. 304 c.

14. Федоренко В.Ф. Повышение ресурсоэнергоэффективности агропромышленного комплекса. М.: ФГБНУ «Росинформагротех». 2014. 284 с.

15. Немцов А.Е. Техника - основа развития агропромышленного комплекса // Инновации и продовольственная безопасность. 2015. № 2(8). C. $60-64$.

16. Жалнин Э.В. Агропромышленный комплекс России - стагнация или развитие? // Тракторы и сельхозмашины. 2012. № 7. С. 3.

17. Александрова А.В., Андросенко Н.В., Басарева В.Г., Бахмутская А.В., Борисов А.А., Вертакова Ю.В., Волкова А.А., Глухов В.В. и др. Экономика и промышленная политика: теория и инструментарий : колл. моногр. / под ред. д-ра экон. наук, проф. А.В. Бабкина. СПб.: Изд-во СПбГПУ, 2014. $612 \mathrm{c}$.

18. Стратегия социально-экономического развития агропромышленного комплекса Российской Федерации на период до 2020 года (научные основы). М.: PACXH. 2011. 101 с. URL: http://www. vniiesh.ru/documents/document_9509_\%D0\%A1\%D1 \%82\%D1\%80\% D0\%B0\%D1\%82\%D0\%B5\%D0\%B3\% D0\%B8\%D1\%8F\%20\%D0\%90\%D0\%9F\%D0\%9A\%2 02020.pdf (дата обращения: 08.07.2016).

19. О устойчивого стратегии развития сельских территорий РФ на период до 2030 г.: Распоряж. Правительства РФ № 151-р от 02.02.2015 г. URL: http://government.ru/media/files/Fw1kbNXVJx Q.pdf (дата обращения: 30.07.2016).

20. Информационный справочник о мерах и направлениях государственной поддержки агропромышленного комплекса PФ. URL: http://www. gp.specagro.ru/ (дата обращения: 03.08.2016).

21. Информационный справочник о мерах и направлениях государственной поддержки агропромышленного комплекса РФ. URL: http://www.gp.specagro.ru/region/rf/30/12/2015 (дата обращения: 03.08.2016).

22. Manyika J. Chui M., Bughin J., Dobbs R., Bisson P., Marrs A. Disruptive technologies: advances 
that will transform life, business, and the global economy. McKinsey Global Institute, 2013. URL: http://www.mckinsey.com/business-

functions/business-technology/our-insights/disruptivetechnologies (accused July 12, 2016).

23. Российский инновационный индекс / под ред. Л.М. Гохберга. М.: Высшая школа экономики, 2011. 84 с.

24. Enabling Smart Farming in Europe. URL: http://www.cema-agri.org/page/enabling-smartfarming-europe (accused June 13, 2016).

25. Алетдинова А.А. Диффузия smart-технологий как парадигма перехода к седьмому технологическому укладу // Теория устойчивого развития экономики и промышленности / под ред. А.В. Бабкина. СПб.: Изд-во Санкт-Петербургского политехн. ун-та Петра Великого, 2016. С. 55-77.

26. Орловская область и Беларусь обсуждают развитие проектов ГЛОНАСС для сельского хозяйства // Новости интернет вещей. URL: https://iot.ru/selskoe-khozyaystvo/2808orlovskaya_ob lasts_i_belaruss_obsuzhdaut_razvitie_proektov_glonass _dlya_selsskogo_hozyajstva (дата обращения: 20.09.2016).

27. Первый прототип самоуправляемого трактора представлен в Казани // Новости интернет вешей. URL: https://iot.ru/selskoe-khozyaystvo/p rototippervogo-samoupravlyaemogo-traktora-predstavlen-vkazani (дата обращения: 20.09.2016).

28. Ананьев А.Н. Проблемы применения роботов в сельскохозяйственном производстве. URL: http://www.biz-for.ru/robotics/robotsprobl/robotsprobl .php (дата обращения: 18.08.2016).

ALETDINOVA Anna A. - Novosibirsk State Technical University.

630073. K. Marksa av. 20. Novosibirsk. Russia. E-mail: aletdinova@corp.nstu.ru

АЛЕТДИНОВА Анна Александровна - доцент Новосибирского государственного технического университета, кандидат технических наук.

630073, пр. К. Маркса, д. 20, г. Новосибирск, Россия. E-mail: aletdinova@corp.nstu.ru 